\title{
THE EFFECT OF TECHNICAL EFFICIENCY ON THE COMPETITIVENESS OF CASSAVA INDONESIA
}

\author{
Yohana Julina Sinaga $^{* 1}$, Nunung Kusnadi*), Dwi Rachmina ${ }^{*}$ \\ ${ }^{*}$ Department of Agribusiness, Faculty of Economics and Management, IPB University \\ Jl. Kamper Wing 4 Level 5 Kampus IPB Dramaga 16680 Bogor, Indonesia
}

\begin{abstract}
Over the past 10 years, cassava imports in the form of semi-finished products have tended to increase. This study aims to analyze the comparative advantages and competitive advantages of fresh cassava at the farming and processed cassava level in the processing industry. The research used secondary data covering 2.595 cassava farmers in all provinces in Indonesia obtained from Agricultural Census 2013 - Central Bureau of Statistics (BPS), while data on the cassava processing industry was obtained from the publication of Bank Indonesia. The Policy Analysis Matrix (PAM) method was used to measure cassava's comparative and competitive advantages and further analyzed based on the technical efficiency score of the farm allegedly by the Data Envelopment Analysis (DEA) method. Results from PAM Analysis showed that Indonesian cassava products both in the farming and processing industry levels were not competitive. The technical efficiency of cassava production becomes the determinant of competitiveness the more efficient the production at the farm level, the competitiveness of cassava the higher. The competitiveness of the cassava processing industry is determined by the government's intervention in the price of cassava. The cassava processing industry pays for raw materials higher than it should. The implications of this study are to improve the competitiveness of Indonesian cassava products need to increase the efficiency of cassava farming production and government policies related to the selling price of fresh cassava to protect farmers and the cassava processing industry.
\end{abstract}

Keywords: competitiveness, policy analysis matrix, technical efficiency, cassava

\begin{abstract}
Abstrak: Selama 10 tahun terakhir, impor ubi kayu dalam bentuk produk setengah jadi cenderung meningkat. Penelitian ini bertujuan menganalisis keunggulan komparatif dan keunggulan kompetitifubi kayu segar di tingkat usahatani dan ubikayu olahan pada industri pengolahan. Penelitian ini menggunakan data sekunder yang mencakup 2.595 petani sampel di seluruh provinsi di Indonesia diperoleh darihasil Sensus Pertanian 2013, Badan Pusat Statistik (BPS), sedangkan data industri pengolahan ubi kayu diperoleh dari publikasi Bank Indonesia. Keunggulan komparatif dan keunggulan kompetitif dianalisis menggunakan metode Policy Analisis Matrix (PAM) dan dianalisi lebih lanjut berdasarkan skor efisiensi teknis usahatani yang diduga denganmetode Data Envelopment Analysis (DEA). Hasil analisis PAM menunjukkan produk ubi kayu Indonesia baik dalam bentuk segar di tingkat usahatani maupun dalam bentuk olahan di tingkat industri pengolahan tidak berdayasaing. Efisiensi teknis produksi ubi kayu menjadi penentu daya saing. Semakin efisien produksi di tingkat usahatani daya saing ubi kayu semakin tinggi.Daya saing industri pengolahan ubi kayu ditentukan oleh intervensi pemerintah terhadap harga ubi kayu. Industri pengolahan ubi kayu membayar bahan baku lebih tinggi dari yang seharusnya. Implikasi dari hasil penelitian ini adalah untuk meningkatkan daya saing produk ubi kayu Indonesia perlu adanya peningkatan efisiensi produksi usahatani ubi kayu dan kebijakan pemerintah terkait harga jual ubi kayu segar untuk melindungi petani dan industri pengolahan ubi kayu.
\end{abstract}

Kata kunci: daya saing,policy analysis matrix, efisiensi teknis, ubi kayu

\footnotetext{
${ }^{1}$ Corresponding author:

Email: yohanajulina@gmail.com
} 


\section{INTRODUCTION}

Indonesia is one of the five largest cassava-producing countries in the world. Four other countries are the largest producers of cassava globally, namely Nigeria, Thailand, Brazil, and Congo (FAOSTAT, 2019). However, during the last 10 years (2010-2019), Indonesia is still an importer of cassava in the form of semi-finished products, namely starch, pellets, chips, and coarse flour. Indonesian cassava imports (20092018 ) tend to increase by around $24.95 \%$ per year.

In the last 10 years (2008-2017), Indonesian cassava production has tended to decline at a rate of $-1.27 \%$ per year (BPS, 2018). The decline in production was largely due to a sharp decline in the harvested area for cassava, namely $-4.2 \%$ per year. On the other side, the productivity of Indonesian cassava tended to increase with an average increase of $3.58 \%$ per year. Compared to Thailand, Thailand's cassava production was higher than Indonesia's cassava production and tended to increase by $3.58 \%$ per year. The increase in cassava production in Thailand was due to an increase in harvested area (1.74\% per year). However, the productivity of Thai cassava was lower than the productivity of Indonesian cassava (FAOSTAT, 2018).

In 2007-2013 the decrease in cassava harvest area was quite significant compared to other food crops, namely -7.65 percent per year (BPS, 2018). One of the causes of the widespread decline in cassava harvest is the price of cassava at a very low producer level. Based on Asnawi and Mejaya (2016) research, in 2016, the selling price of cassava at the producer level was Rp700.00/kg while the selling price of corn at the producer level was $\mathrm{Rp} 2,100.00 / \mathrm{kg}$.

Cassava production at the farm level was decreasing due to a decrease in the harvested area resulting in insufficient national supply to meet the needs of cassava, especially at the level of the processing industry. This condition caused the processing industry to fulfil its raw material needs by importing semi-finished cassava products in starch, pellets, chips, and coarse flour. Another difficulty faced by the tapioca flour processing industry in Indonesia was the absence of policies that supported the food processing industry, which had made the flour industry tapioca experienced a downturn (Ministry of Trade Republic of Indonesia, 2017).
Asriani (2011) mentioned that Gaplek and Tapioca Indonesia have strong competitiveness and tend to be exporters. However, for starch products, Indonesia has low competitiveness and tends to be an importer. When compared to Thailand, Suwannarat (2017) mentioned that cassava Thailand has a very high comparative advantage. In addition, Thailand also has a large enough market share for its cassava products. According to Rachmat and Nuryanti (2015), Indonesia needs to improve efficiency, product quality, and strong competitiveness to achieve domestic and international market opportunities. Therefore, improvements to production, post-harvest and processing systems should be considered.

Daryanto (2009) and Latruffe (2010) mentioned that the essence of an industry's competitiveness is efficiency and productivity. Therefore, one of the efforts that can be made to improve the competitiveness of a commodity from a micro perspective is to increase efficiency and productivity. Improving productivity through technical efficiency will create comparative advantages for a commodity that can improve its competitiveness.

Based on this description, it was important to study whether Indonesian cassava at the farm and processing industry levels has competitiveness? Besides, the effect of technical efficiency on the competitiveness of cassava needs to be studied to see an increase in cassava production. This needs to be researched because research on the competitiveness of cassava that has been done only looks it in general without regard to aspects of its technical efficiency. Therefore, imports of cassava processing products also continue to increase every year.

\section{METHODS}

The data used in this study are data from the 2013 Agricultural Census, the Palawija Plant Household Business Survey for cassava commodities obtained from the Statistics Indonesia (BPS), and the publication of the Central Bank of Indonesia on Small Business Financing Patterns (PPUK) for tapioca flour processing in 2009. The sample farmer data used were 2.529 farmers from all provinces in Indonesia. The supporting data used were data on the development of Indonesia's export-import in 2009 and 2013 and the FOB value for cassava output, fertilizer, and tapioca flour output. The method used in this research was the Policy Analysis 
Matrix (PAM), as presented in Table 1. PAM identifies three main problems of competitiveness, specifically the impact of policies on competitiveness and profits, the effect of investment policies on economic efficiency and comparative advantage, and the effect of agricultural policy in the form of technological changes (Monke and Pearson, 1989)

The competitiveness of cassava in this study was analyzed at two production levels, namely in the farming and processing industry levels used PAM. PAM Matrix is considered a deterministic model or a model that uses numbers whose results are assumed to be precise. This is not necessarily true because the PAM model only uses one price level, while the price is very varied in actual circumstances. Therefore, factors that are a source of diversity or uncertainty are very important to note. In this study, the competitiveness of sweet potatoes was measured by paying attention to the diversity of technical efficiency, which was divided into five categories. The technical efficiency score was calculated using Data Envelopment Analysis (DEA) method. In this study, it is suspected that the level of technical efficiency affects its competitiveness. The results of this study are expected to see the relationship of technical efficiency to the competitiveness of cassava, so that policy recommendations can be obtained to improve the competitiveness of Indonesian cassava products. The concept can be seen in the research framework presented in Figure 1.

Table 1. The PAMMatrix

\begin{tabular}{|c|c|c|c|c|}
\hline \multirow{2}{*}{ Details } & \multirow{2}{*}{ Revenue } & \multicolumn{2}{|c|}{ Costs } & \multirow{2}{*}{ Profits } \\
\hline & & Tradable Input & Domestic Factors & \\
\hline Private Price & Private revenue & $\begin{array}{l}\text { Private costs of tradable } \\
\text { input }\end{array}$ & $\begin{array}{l}\text { Private costs ofdomestic } \\
\text { factors }\end{array}$ & $\begin{array}{l}\text { Private profits } \\
(\mathrm{A}-(\mathrm{B}+\mathrm{C}))\end{array}$ \\
\hline Social Price & Social revenue & $\begin{array}{l}\text { Social costs of tradable } \\
\text { input }\end{array}$ & $\begin{array}{l}\text { Social costs of domestic } \\
\text { factors }\end{array}$ & Social profits $(\mathrm{E}-(\mathrm{F}+\mathrm{G}))$ \\
\hline Divergences & Output transfers (A-E) & Input transfers $(\mathrm{B}-\mathrm{F})$ & Factor transfers $(\mathrm{C}-\mathrm{G})$ & Net transfers (I-J-K) \\
\hline
\end{tabular}

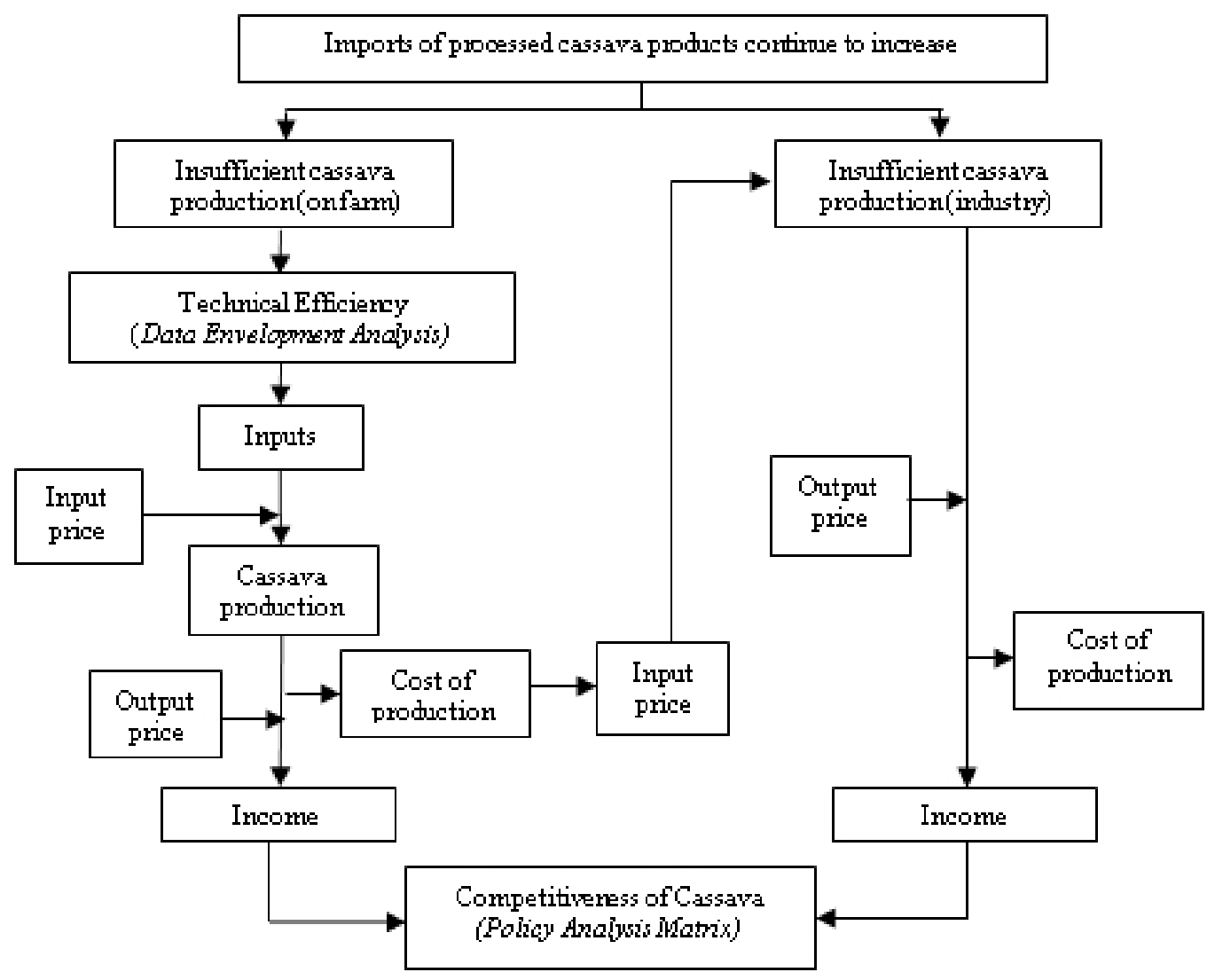

Figure 1. Research framework 


\section{RESULTS}

\section{Competitivenes of Cassava Indonesia in General}

The competitiveness of Indonesian cassava is analyzed using the Policy Analysis Matrix (PAM). In Table 2, it was known that the private profit of cassava farming showed a positive value, namely 12,20 million rupiahs. This was in line with Rosanti et al. (2018) research, which stated that, in general, cassava farming in Lampung Province had positive private profit values. A positive private profit value indicated that cassava farming was indicated to obtain a sub-normal rate of return, or in other words, it was financially feasible to run with government policies. The personal benefits of cassava farming could still be increased if the use of inputs was efficient.

It was inversely proportional to the private profit at the farm level. The private profit received by the industrial owner was negative at the level of the processing industry, namely -50.19 million rupiahs. This was different from the research of Endaryanto et al.(2020), whose results showed that, in general, the tapioca processing industry in Lampung Province had positive private profit values. The negative value of private profits in this study indicated that the cassava processing industry was indicated to obtain a subnormal rate of return, or in other words, it was not financially feasible to run even though there had been government intervention through policy. This occurred because the profits earned could not meet the costs of tradable inputs and domestic factors.

The value of private profit was closely related to the value of PCR, where the higher the private cost of domestic factors incurred, the greater the value of the PCR obtained. PCR values greater than or more than one indicated that the farming system or processing industry did not have a competitive advantage. In cassava farming, the PCR value obtained was 0.48 or less than one. This showed that an additional domestic factor cost of 0.48 rupiah per unit was required to get an additional output of one unit.

PCR values less than one indicated that cassava farming had a competitive advantage. It was inversely proportional to cassava farming. The PCR value obtained was more than one in the cassava processing industry, namely 2,06. This showed that an additional domestic factor cost of 2.06 rupiah per unit was required to get an additional output of one unit. A PCR value that was more than one indicated that the cassava processing industry did not have a competitive advantage.

Based on Table 2, it was also known that the value of social benefits in cassava farming had a negative value, namely -0.14 million rupiahs. This was different from Rosanti et al.(2018) research, which stated that, in general, the social benefits of cassava farming in Lampung Province had a positive value. The negative social benefit value in this study indicated that the agricultural system was not economically profitable without intervention from the government.

In contrast to the social benefits at the farm level, the social benefits received by industrial owners were positive for the processing industry. This was similar to the research of (Endaryanto et al. 2020), which stated that, in general, the tapioca processing industry in Lampung Province had positive social benefits. The results of the analysis of the social benefits of the cassava processing industry, which were higher than the private profits, were due to the high production costs incurred by the company to keep producing and not balanced with high selling prices at the actual price level.

Table 2. Policy Analysis Matrix (PAM) cassava farming based on the level of technical efficiency (based on kg/ ha)

\begin{tabular}{|c|c|c|c|c|c|c|c|c|}
\hline \multirow[b]{2}{*}{ Details } & \multirow[b]{2}{*}{ Revenue } & \multicolumn{2}{|c|}{ Costs } & \multirow[b]{2}{*}{ Profits } & \multirow[b]{2}{*}{ Revenue } & \multicolumn{2}{|c|}{ Costs } & \multirow[b]{2}{*}{ Profits } \\
\hline & & $\begin{array}{c}\text { Tradable } \\
\text { Input }\end{array}$ & $\begin{array}{c}\text { Domestic } \\
\text { Factors }\end{array}$ & & & $\begin{array}{c}\text { Tradable } \\
\text { Input }\end{array}$ & $\begin{array}{c}\text { Domestic } \\
\text { Factors }\end{array}$ & \\
\hline Privat Prices & 25.18 & 1.54 & 11.44 & 12.20 & 60.50 & 12.98 & 97.70 & $(50.19)$ \\
\hline Social Prices & 12.88 & 2.04 & 10.99 & $(0.14)$ & 230.94 & 17.97 & 83.95 & 134.09 \\
\hline Divergences & 12.29 & $(0.50)$ & 0.45 & 12.35 & (170.45) & (4.99) & 13.74 & (184.28) \\
\hline
\end{tabular}


The value of social benefits was closely related to the value of the DRCR, where the higher the social cost of domestic factors incurred, the greater the DRCR value obtained. DRCR values greater than or more than one indicated that the farming system or processing industry did not have a comparative advantage. In cassava farming, the DRCR value obtained was 1,01 or more than one. This showed that the proportion of domestic resource costs was higher than the import price. In other words, for every one rupiah the state spent on importing cassava, it required a domestic resource cost of 1,01 rupiah to produce cassava in the country. DRCR value that was more than one indicated that cassava farming did not have a comparative advantage. It was inversely proportional to cassava farming. The DRCR value obtained was less than one in the cassava processing industry, namely 0,39 . The DRCR value of less than one indicated that the cassava processing industry had a comparative advantage.

Based on the above, it was known that the cassava farming and processing industry were not yet competitive. Cassava farming only had a competitive advantage but did not have a comparative advantage. The DRCR value greater than the PCR value in cassava farming indicated a government policy to increase the efficiency of farmer production. On the other hand, the cassava processing industry only had a comparative advantage and no competitive advantage. The smaller DRCR value than the PCR value indicated that the cassava processing industry had not been supported by government policies to increase production efficiency.

\section{Competitivenes of Cassava Indonesia Based on The Level of Technical Efficiency}

After looking at the competitiveness of cassava in general, then the competitiveness of cassava both at the level of farming and processing industry is also measured based on the technical level efficiency and divided into several levels of categories. Based on previous research, it is known that the level of technical efficiency of Indonesian cassava has not been efficient. This is evident from the research of Manihuruk et al.(2018), which stated that cassava farming with monoculture and intercropping patterns in Central Lampung was not technically efficient, and Anggraini et al.(2017) research which stated that cassava farming in Central Lampung was not technically efficient because the average efficiency value was 0.69 . Therefore, it is necessary to see the effect of the technical efficiency of cassava farming on its competitiveness.

\section{Profit Analysis}

Profit analysis indicators consisted of personal and social benefits. The results of PAM analysis for private and social benefits can be seen in Figure 2 and Figure 3. In Figure 2, it was known that the private profit of cassava farming showed a positive value. From Figure 2 , it was also known that the private profits of cassava farming tended to increase along with the increase in technical efficiency. The higher the technical efficiency of the farmers was, the lower the production costs incurred by the farmers for both tradable input and domestic factors costs would be. On the other side, farmers' income increased due to increased production and the price of cassava. This, of course, would significantly impact the increase in profits received by farmers. A positive private profit value indicated that cassava farming had a supernormal rate of return.

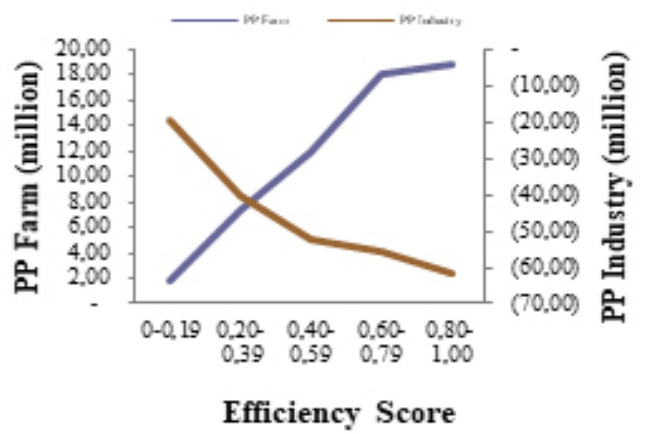

Figure 1. Value of private profit (PP) in cassava farming and cassava processing industry

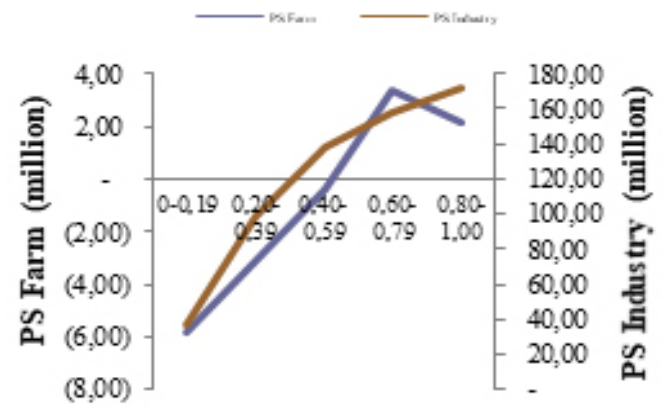

Efficiency Score

Figure 2. Value of social benefits (PS) of cassava farming and cassava processing industry 
In Figure 2, private profits received by industry owners is a negative value at the industry level. The negative value of private profits in this study indicates that the cassava processing industry is indicated to have a subnormal rate of return. If studied according to the technical efficiency index, the higher level of technical efficiency cassava farming, the production of cassava produced to become industrial raw materials more and more. If the industry is likened to accommodating all the production, this will undoubtedly increase the cost of industrial raw materials. The more raw materials used will also increase other operational costs, such as labour. As a result, production costs in the cassava processing industry will increase, causing losses.

Based on the technical efficiency score, Figure 3 showed that the social profits obtained were negative in cassava farming, with an efficiency level of 0-0.59. Then, it tended to increase with the increase in the level of technical efficiency. The negative social gains were due to the cost of tradable inputs to the increasing and domestic factors. However, as technical efficiency levels increased, the tradable input costs continued to decline. This decrease was due to the use of tradable inputs to the reduced. This made the social benefits positive at the efficiency level of 0.60-1.00.

In this study, it was also known that the social profits received by industrial owners had positive values at all levels of technical efficiency. In Figure 3, it could be seen that the value of social profits tended to increase with increasing levels of technical efficiency. This occurred because the higher the technical efficiency level was, the higher the production of cassava produced as industrial raw material and the cheaper the price of cassava purchased by the industry. The large number of raw materials obtained by the industry would cause the production of tapioca flour to increase. Besides, the high social price of wheat flour was also one of the reasons for the increase in the social profits of the cassava processing industry.

Based on the indicators of private profits and social benefits of cassava farming, it could be seen that only $30.97 \%$ of all farmers had positive values of personal and social benefits. In contrast, the remaining $69.03 \%$ of farmers had negative social benefits. Meanwhile, the cassava processing industry had negative private profit values but positive social benefit values at all technical efficiency levels. The value of private profits that was smaller than the social benefits in the cassava processing industry indicated that the domestic price of tapioca flour had not received protection from the government, so the profits received by the tapioca processing industry were lower than they should be.

\section{Analysis of CompetitiveAdvantage and Comparative Advantage}

Another indicator to measure the competitiveness of cassava is the competitive and comparative advantage seen from the PCR and DRCR (Figure 4 and Figure 5 ). Based on the technical efficiency index, the PCR value of cassava farming was less than one and tended to decrease along with the level of technical efficiency. PCR values that were less than one indicated that cassava farming had a competitive advantage. It means that it only needs an additional domestic resource cost of less than one rupiah at private prices to generate a value-added of one unit of output in cassava farming. The higher the technical efficiency level of the farmers was, the lower the production costs incurred by the farmers for both tradable input and domestic factors costs. On the other side, farmers' income increased due to increased production and the price of cassava. This, of course, would significantly impact the increase in profits received by farmers. This showed that the higher the level of technical efficiency, the more competitive advantage would increase. PCR value is related to the personal value, where the lower the private costs of domestic factors, the smaller the value of PCR, which means the farming system did have to generate competitive advantages.

The PCR value of the cassava processing industry showed a value of more than one, which meant that the cassava processing industry did not have a competitive advantage. In other words, the production system of the cassava processing industry can not pay the cost of its domestic factors. PCR values that more than one due to the high production costs incurred to produce tapioca. However, the PCR value obtained was tended to decrease along with the increase in the level of technical efficiency, which meant that if the industry cooperates with farmers whose technical efficiency levels were higher, the competitive advantage would also be increased. 


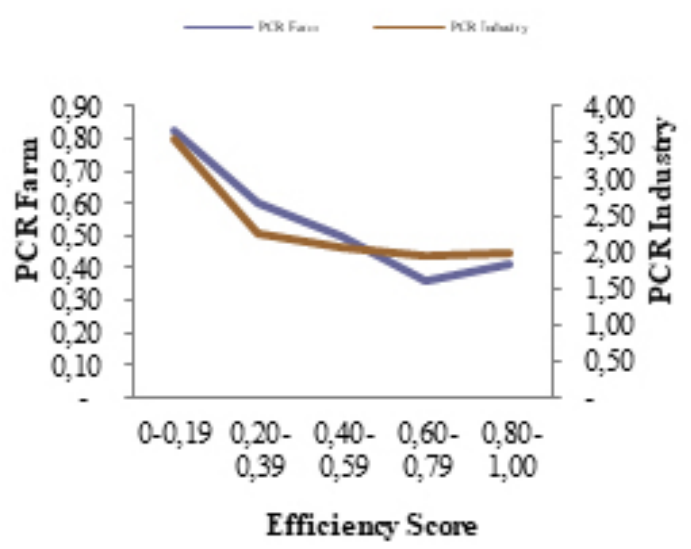

Figure 3. PCR values for cassava farming

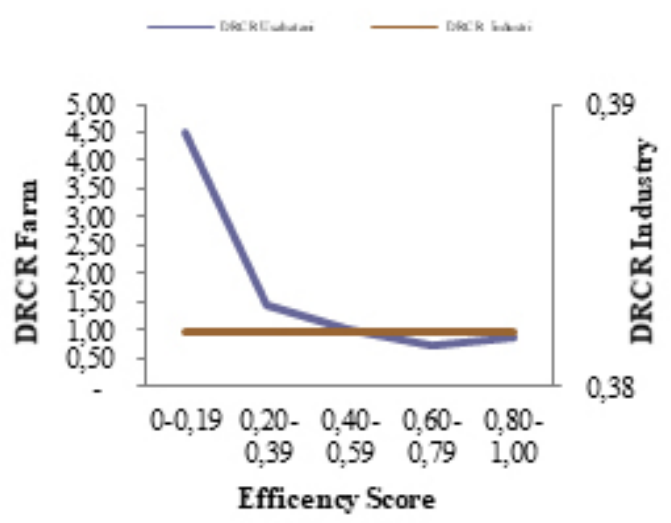

Figure 4. DRCR value of cassava farming
The DRCR value of cassava farming tended to decrease along with the increase in technical efficiency. This meant that the higher the technical efficiency of Indonesian cassava was, the more its comparative advantage would be. In farms with an efficiency level of $0-0.59$, the DRCR value was more than one, which meant that cassava farming did not have a comparative advantage. The DRCR value was more than one, indicating that domestic resource costs are higher than the import price. In other words, every one rupiah that Indonesia spent on importing cassava needs more than one rupiah of domestic resource cost to produce cassava in Indonesia.

However, along with the increase in technical efficiency, the DRCR value obtained was getting smaller so that the efficiency level of 0.60-1.00 cassava farming had a comparative advantage. This is due to as technical efficiency levels increased, the tradable input costs continued to decline. This decrease was due to the use of tradable inputs to the reduced. DRCR value is related to the social value, where the lower the social costs of domestic factors, the smaller the value of DRCR, which means the farming system did have to generate comparative advantages.

The DRCR value of the cassava processing industry tended to decrease along with the increase in technical efficiency and showed a value of less than one.

The DRCR value that less than one means that when the industry collaborated with farmers whose level of technical efficiency was higher, the comparative advantage of the processing industry would also increase without assistance and intervention from the government. The DRCR value was less than one indicating that the proportion of domestic resource costs is lower than the import price. In other words, every one rupiah that Indonesia spent on importing cassava needs less than one rupiah of domestic resource cost to produce cassava in Indonesia. A DRCR value of less than one indicated that tapioca flour was better produced domestically than importing. In fact, at this time, the import of tapioca flour continued to increase every year.

Based on indicators of competitive and comparative advantages in cassava farming, it could be seen that only $30.97 \%$ of all farmers had competitive and comparative advantages. Meanwhile, the remaining $69.03 \%$ of farmers only had a competitive advantage. The results of this study were similar toPramesti et al.(2018), which stated that the Indonesian cassava commodity did not have a comparative advantage compared to other countries but had a competitive advantage. The PCR value in cassava farming had a higher value than the DRCR value. This showed that the cassava commodity produced had not been supported by government policies in terms of increasing the efficiency of cassava production (Setiawan et al. 2014)

The value of competitive and comparative advantages in the cassava processing industry showed that the industry had a comparative advantage but did not have a competitive advantage. The results of this study were in line with Asriani (2011) research which stated that Indonesian cassava starch products had low competitiveness and tended to be importers. Therefore, in the future, Indonesia must be able to increase the productivity of cassava products, even though it had a comparative advantage, but from year to year, the trend of its development showed negative results. 
Based on Taslim and Rifin (2020) research, the quantity of imported cassava products (tapioca) does not affect the price of cassava. However, the price of imported tapioca can significantly affect the price of Indonesian cassava. The role of the government in maintaining affordable prices for cassava is necessary so that the cassava processing industry can continue to operate. The income of cassava farmers must also remain high even though the price they receive is low. Therefore, farmers must increase their cassava production and productivity. One of them is by implementing agricultural extension and intensification programs.

According to Amilia and Choiron (2017), the competitiveness of the tapioca flour processing industry could be done by increasing the efficiency of tapioca flour products, such as improving product quality, optimizing workforce performance, and managing the supply of raw and auxiliary materials. Added by Nabay et al. (2017), some things to note to improve the competitiveness of the cassava processing industry are strong farmer linkages, promotion of improved varieties, access to mechanization, improved infrastructure, better awareness of cassava's potential, and product promotion. While according to Suroso (2019), some strategies that should be done to empower the tapioca industry are implementing sustainability policies and developing tapioca production quantity.

\section{Impact of Government Policy}

The impact indicators of government policies are shown by the value of NPCO for output policies, NPCI for input policies, also EPC and PC for input-output policies. The value of NPCO, NPCI, EPC, and PC can be seen in Table 3. In Table 3, it was known that the NPCO value of cassava farming obtained from all categories of efficiency levels was worth more than one, which meant that farmers received subsidies for cassava sold in the domestic market. In contrast to cassava farming, in the cassava processing industry, the NPCO value obtained at each level of the efficiency category was less than one, which meant a reduction in industry revenue due to policies related to wheat flour products from the government, for example, taxes.

The NPCI value in the cassava farming and processing industry obtained from all categories of efficiency levels was less than one. This showed that domestic prices were lower than world prices, which meant a subsidy policy from the government for tradable inputs. The EPC value of cassava farming from all categories of efficiency levels was worth more than one, which meant that the protection from the government for the cassava commodity was very high. This was indicated by the higher price of cassava that applied when compared to the social price. Meanwhile, the value of the profit coefficient $(\mathrm{PC})$ of cassava farming obtained in cassava farming with an efficiency level of 0-0.59 was negative, which meant that the policies made by the government had no impact on creating incentives for farmers with an efficiency level of 0-0. 59. Conversely, for farms with an efficiency level of 0.60-1.00, the profit coefficient (PC) was positive, which meant that the policies made by the government had an impact in the form of creating incentives for farmers.

In the cassava processing industry, the EPC value obtained from all the efficiency level categories was less than one, which meant that the protection from the government for tapioca flour products was meagre. This would impact the current price of tapioca flour, which would be lower than the social price. Meanwhile, the PC value of the cassava processing industry was negative, which meant that the policies made by the government did not have an impact on the creation of incentives for the owner of the cassava processing industry.

Table 3. Value NPCO, NPCI, EPC, and PC farming and industrial processing of cassava

\begin{tabular}{ccccccccc}
\hline \multirow{2}{*}{ Efficiency Level } & \multicolumn{4}{c}{ Farm } & \multicolumn{5}{c}{ Processing Industry } \\
\cline { 2 - 10 } & NPCO & NPCI & EPC & PC & NPCO & NPCI & EPC & PC \\
\hline $0.00-0.19$ & 3.05 & 0.52 & 5.85 & $(0.29)$ & 0.26 & 2.56 & 0.13 & $(0.52)$ \\
$0.20-0.39$ & 2.10 & 0.73 & 2.52 & $(2.34)$ & 0.26 & 1.32 & 0.20 & $(0.40)$ \\
$0.40-0.59$ & 1.93 & 0.83 & 2.16 & $(30.28)$ & 0.26 & 1.03 & 0.22 & $(0.37)$ \\
$0.60-0.79$ & 1.96 & 0.80 & 2.14 & 5.32 & 0.26 & 0.77 & 0.23 & $(0.35)$ \\
$0.80-1.00$ & 2.00 & 0.57 & 2.15 & 8.92 & 0.26 & 0.85 & 0.23 & $(0.35)$ \\
\hline
\end{tabular}




\section{Managerial Implication}

Based on the results above, it was known that the technical efficiency of cassava farming was closely related to the competitiveness of the cassava farming and processing industry. The higher the level of technical efficiency of farming, th lower the production costs due to the optimal use of inputs. The reduction in production costs would increase the profits of the cassava farming and processing industry and impact the competitiveness of the cassava commodity. The results of this study were in line with the research of Nivievskyi and Brummer (2010), which stated that one of the factors that determined the competitiveness of a commodity was the level of technical efficiency of commodity farming. Technically efficient cassava farming would produce optimal output based on the production factors used. This could increase the comparative advantage of the cassava commodity to compete with other commodities both at home and abroad.

\section{CONCLUSIONS AND RECOMMENDATIONS}

\section{Conclusions}

Based on the results obtained, it was known that Indonesian cassava products both in the farming and processing industry were not competitive. Cassava at the farm level did not have a comparative advantage. This is due to the low price of cassava compared to tradeable input prices and domestic factors when there is no intervention from the government. At the processing industry level, processed cassava products did not have a competitive advantage. This is due to the high price of cassava (raw materials) paid by the industry compared to what it should be. This causes the industry to spend more production costs. This is one of the reasons Indonesia continues to import processed cassava products every year. When viewed from the level of technical efficiency, the higher the level of technical efficiency was, the comparative advantage of cassava farming and the competitive advantage of the cassava processing industry was also increasing. Based on this, it was known that the higher the level of technical efficiency would impact the improvement of the competitiveness of Indonesian cassava.

\section{Recommendations}

One of the efforts that can be made to improve the competitiveness of Indonesian cassava is by increasing the technical efficiency of cassava farming. Therefore, the role of the government is needed to provide information to farmers regarding the optimal use of inputs. Besides, special attention needs to be given to the policy on the price of cassava and the price of processed cassava products by the government so that farmers and the national cassava processing industry can be protected and the competitiveness of Indonesian cassava can increase.

\section{REFERENCES}

Amilia W, Choiron M. 2017. Studi Kelayakan Usaha dan Daya Saing pada Industri Tepung Tapioka di Kecamatan Pogalan Kabupaten Trenggalek. Journal of Social and Agricultural Economics10(2):51-57.https://doi. org/10.19184/jsep.v10i2.5654..

Anggraini N, Harianto H, Anggraeni L. 2017. Efisiensi teknis, alokatif dan ekonomi pada usahatani ubikayu di Kabupaten Lampung Tengah Provinsi Lampung. Jurnal Agribisnis Indonesia 4(1). https://doi.org/10.29244/jai.2016.4.1.43-56.

Asnawi R, Mejaya MJ. 2016. Analisis keunggulan kompetitifubikayu terhadapjagung dan kedelai di Kabupaten Lampung Tengah. Jurnal Penelitian Pertanian Tanaman Pangan 35(3): 209-215. https://doi.org/10.21082/jpptp.v35n3.2016. p209-215.

Asriani PS. 2011. Analisis daya saing ekspor ubi kayu Indonesia. Journal Agroland 18(1): 65-70.

Daryanto A. 2009. Posisi Daya Saing Pertanian Indonesia dan Upaya Peningkatannya. Jakarta: Pusat Sosial Ekonomi dan Kebijakan Pertanian.

Endaryanto T, Zakaria W, Affandi M, Indah L. 2020. Global Conferences Series: Impact of tapioca factories on the competitiveness of cassava Pengaruh keberadaan pabrik tapioka terhadap daya saing ubikayu. Global Conferences Series Sciences and Technology 5(1):54-58.

[BPS] Badan Pusat Statistik. 2018. Luas Panen Tanaman Pangan Indonesia. Jakarta: BPS.

[FAOSTAT] Food and Agriculture Organization. 2018. Cassava-Crops (Indonesia Production) http:// www.fao.org/faostat.

[FAOSTAT] Food and Agriculture Organization. 2019. 
Cassava-Crops (Production)http://www.fao.org/ faostat.

Kementerian Perdagangan. 2013. Penetrasi Pasar Cassava Starch (TepungTapioka) di Filipina. KBRI-Manila.

Latruffe L. 2010. Competitiveness, Productivity and Efficiency in the Agricultural and Agri-Food Sectors. OECD Food, Agric Fish Pap. 30(30).

Manihuruk EM, Harianto H, Kusnadi N. 2018. A Analisis faktor yang memengaruhi petani memilih pola tanam ubi kayu serta efisiensi teknis di Kabupaten Lampung Tengah. Jurnal Agrisep 17(2):139-150.https://doi.org/10.31186/ jagrisep.17.2.139-150.

Monke EA, Pearson SR. 1989. The Policy Analysis Matrix for Agricultural Development. London: Cornell University Press

Nabay O et al. 2017. Assessing the Efficiencies and Competitiveness of the Fresh Cassava Storage Root Production Systems in Sierra Leone. The Journal of Agricultural Science 9(12). https:// doi.org/10.5539/jas.v9n12p178.

Nivievskyi O, Brummer B. 2010. A Note on Technical Efficiency Productivity Growth and Competitiveness. Germany: University of Göttingen.
Pramesti FS, Rahayu ES, Agustono A. 2018. Analisis daya saing ubi kayu Indonesia di pasar internasional. Jurnal Sosial Ekonomi Pertanian dan Agribisnis 14(1): 1-7. https://doi. org/10.20961/sepa.v14i1.21034.

Rachmat M, Nuryanti S. 2015. Daya saing produk olahan pertanian: ubi kayu, pisang dan jeruk. Di dalam: Memperkuat Daya Saing Produk Pertanian.

Rosanti N, Zakaria WA, Hasyim AI, Kasymir E. 2018. Analisis daya saing ubi kayu di Provinsi Lampung. Jurnal Sosial Ekonomi Pertanian 12(1):62-74.

Setiawan K, Hartono S, Suryantini A. 2014. Analisis Daya Saing Komoditas Kelapa Di Kabupaten Kupang. Agritech 34(1):88-93.

Suroso S. 2019. Kebijakanpembangunan pemberdayaan usaha industri tapioka di Kabupaten Pati. Jurnal Litbang10(2):83-93. https://doi.org/10.33658/ jl.v10i2.80.

Suwannarat P. 2017. Ascertaining the competitiveness of Thai exports to PRC. Compet Rev. 27(3). https://doi.org/10.1108/CR-04-2016-0026.

Taslim L, Rifin A. 2020. The impact of tapioca import on cassava prices in the development of tapioca industry in Indonesia. Jurnal Manajemen \& Agribisnis 16(3): 133-141. 